\title{
EXTENT OF THE ACIDIFICATION \\ BY N7-COORDINATED cIS-DIAMMINE-PLATINUM(II) \\ ON THE ACIDIC SITES OF GUANINE DERIVATIVES
}

\author{
Bin Song ${ }^{1}$, Gerda Oswald², Matthias Bastian", \\ Helmut Sigel ${ }^{*}$ and Bernhard Lippert ${ }^{*}$ \\ ${ }^{1}$ Institute of Inorganic Chemistry, University of Basel, Spitalstrasse 51, \\ $\mathrm{CH}-4056$ Basel, Switzerland \\ 2 Department of Chemistry, University of Dortmund, Otto-Hahn-Strasse 6, \\ D-44221 Dortmund, Germany
}

\begin{abstract}
Coordination of two monoprotonated 2'-deoxyguanosine $5^{\prime}$-monophosphate species, $\mathrm{H}$ (dGMP)', via $\mathrm{N} 7$ to cis- $\left(\mathrm{NH}_{3}\right)_{2} \mathrm{Pt}^{2+}$ gives the complex cis- $\left(\mathrm{NH}_{3}\right)_{2} \mathrm{Pt}(\mathrm{H} \cdot \mathrm{dGMP})_{2}$ which is a fourprotonic acid. The corresponding acidity constants were measured by potentiometric $\mathrm{pH}$ titrations $\left(25^{\circ} \mathrm{C} ; I=0.1 \mathrm{M}, \mathrm{NaNO}_{3}\right)$. The first two protons are released from the two $-\mathrm{P}(\mathrm{O})_{2}(\mathrm{OH})^{-}$groups $\left(\mathrm{p} K_{\mathrm{a} / 1}=5.57 ; \mathrm{p} K_{\mathrm{a} / 2}=6.29\right)$ and the next two protons are from the $\mathrm{H}(\mathrm{N} 1)$ sites of the guanine residues $\left(p K_{a / 3}=8.73 ; p K_{a / 4}=9.48\right)$. The micro acidity constants of the various sites are also evaluated. Comparison of these data with those determined for the three-protonic $\mathrm{H}_{2}(\mathrm{dGMP})^{ \pm}$ $\left(\mathrm{p} K_{\mathrm{a} / 1}=2.69\right.$ for the $\mathrm{H}^{+}(\mathrm{N} 7)$ site; $\mathrm{p} K_{\mathrm{a} / 2}=6.29$ for $-\mathrm{P}(\mathrm{O})_{2}(\mathrm{OH})^{-} ; \mathrm{p} K_{\mathrm{a} / 3}=9.56$ for $\left.\mathrm{H}(\mathrm{N} 1)\right)$ shows that on average the $\mathrm{N}-7$-coordinated $\mathrm{Pt}^{2+}$ acidifies the phosphate protons by $\Delta \mathrm{p} K_{\mathrm{a}}=0.36$ and the $H(N 1)$ sites by $\Delta p K_{a}=0.46$. These results are further compared with those obtained previously for cis-( $\left(\mathrm{NH}_{3}\right)_{2} \mathrm{Pt}(\mathrm{L})_{2}$, where $\mathrm{L}=$ 9-ethylguanine or monoprotonated 2'-deoxycytidine 5'-monophosphate. Conclusions regarding platinated DNA are also presented.
\end{abstract}

\section{INTRODUCTION}

There is now much evidence that the anticancer drug, Cisplatin, ${ }^{+}$i.e. cis-diamminedichloro-platinum(II), loses in the cell the chloro ligands and exerts then its biological action

\footnotetext{
${ }^{+}$Abbreviations: cis- $\left(\mathrm{NH}_{3}\right)_{2} \mathrm{Pt}^{2+}=$ cis-diammine-platinum(II); cis- $\left(\mathrm{NH}_{3}\right)_{2} \mathrm{Pt}(\mathrm{dCMP})_{2}^{2-}=\mathrm{Pt}(\mathrm{dCMP})_{2}^{2-}$; cis- $\left(\mathrm{NH}_{3}\right)_{2} \mathrm{Pt}(\mathrm{dGMP})_{2}^{2-}=\mathrm{Pt}(\mathrm{dGMP})_{2}^{2-} ; \operatorname{cis}-\left(\mathrm{NH}_{3}\right)_{2} \mathrm{Pt}(9-\mathrm{EtG})_{2}^{2+}=\mathrm{Pt}(9-\mathrm{EtG})_{2}^{2+} ; \mathrm{dCMP}^{2-}=2^{2}-$ deoxycytidine 5'-monophosphate; dGMP ${ }^{2-}=2^{\prime}$-deoxyguanosine $5^{\prime}$-monophosphate; $(\mathrm{dGMP}-\mathrm{H})^{3-}=\mathrm{N} 1$ deprotonated dGMP ${ }^{2-} ; 9-\mathrm{EtG}=$ 9-ethylguanine; $(9-\mathrm{EtG}-\mathrm{H})^{-}=\mathrm{N} 1$-deprotonated $9-\mathrm{EtG} ; \mathrm{L}$ = general ligand. Species which are given without a charge either do not carry one or represent the species in general (i.e., independent from their protonation degree); which of the two versions applies is always clear from the context.
} 
by the preferred binding of cis- $\left(\mathrm{NH}_{3}\right)_{2} \mathrm{Pt}^{2+}$ to the $\mathrm{N} 7$ sites of the guanine residues of DNA. ${ }^{[1,2]}$ Consequently, the coordination chemistry of cis-diammine-platinum(II) has much been studied, especially its interaction with nucleobases $\left(e . g^{[3,4]}\right)$, as have the metal ionbinding properties of nucleobase derivatives in general $\left(e . g .^{[5,6]}\right)$.

However, so far there is no comprehensive study which examines the effect of N7coordinated cis- $\left(\mathrm{NH}_{3}\right)_{2} \mathrm{Pt}^{2+}$ on the acid-base properties of guanine derivatives. We have recently published some data ${ }^{[7]}$ on cis- $\left(\mathrm{NH}_{3}\right)_{2} \mathrm{Pt}(9-\mathrm{EtG})_{2}^{2+}$ and a preliminary abstract ${ }^{[8]}$ dealing with cis-( $\left(\mathrm{NH}_{3}\right)_{2} \mathrm{Pt}(\mathrm{dGMP})_{2}^{2-}$. The latter study has been completed in the meantime and therefore we are now in the position to compare the effect of N7-coordinated cis$\left(\mathrm{NH}_{3}\right)_{2} \mathrm{Pt}^{2+}$ on the $\mathrm{N} 1$ sites of 9-EtG with that on the corresponding sites of dGMP ${ }^{2-}$ (Figure 1) as well as on the monoprotonated phosphate groups in cis- $\left(\mathrm{NH}_{3}\right)_{2} \mathrm{Pt}(\mathrm{H} \cdot \mathrm{dGMP})_{2}$. The latter effect may further be compared with the situation of monoprotonated 2'-deoxycytidine 5'-monophosphate, $\mathrm{H}(\mathrm{dCMP})^{-}$, if bound via $\mathrm{N} 3$ to cis- $\left(\mathrm{NH}_{3}\right)_{2} \mathrm{Pt}^{2+}$; this complex, i.e. cis$\left(\mathrm{NH}_{3}\right)_{2} \mathrm{Pt}(\mathrm{H} \cdot \mathrm{dCMP})_{2}$ (see Figure 2, vide infra), has also been studied. ${ }^{[9]}$

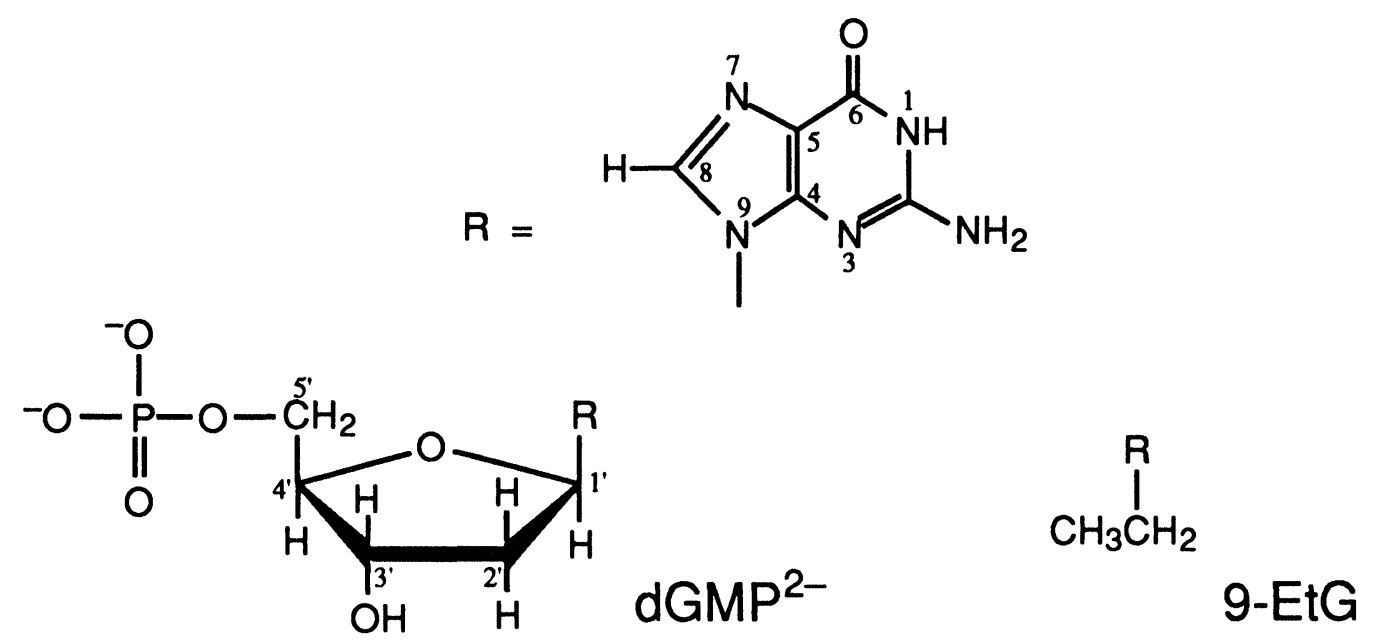

Figure 1. Chemical structures of 2'-deoxyguanosine 5'-monophosphate (dGMP ${ }^{2-}$ ) and of 9-ethylguanine (9-EtG).

\section{MATERIALS AND METHODS}

\subsection{Synthesis of cis- $\left(\mathrm{NH}_{3}\right)_{2} \mathrm{Pt}(\mathrm{dGMP})_{2}^{2-}$}

To a solution of $\mathrm{H}_{2}(\mathrm{dGMP}) \cdot 2 \mathrm{H}_{2} \mathrm{O}(0.53 \mathrm{mmol}, 202 \mathrm{mg})$ in water $(50 \mathrm{~mL})$ is added cis$\left(\mathrm{NH}_{3}\right)_{2} \mathrm{PtCl}_{2}(0.28 \mathrm{mmol}, 84 \mathrm{mg})$ and the $\mathrm{pH}$ is adjusted by means of $\mathrm{NaOH}$ to 7.3. After stirring for 5 days (room temperature, stoppered flask) the sample is filtered from a small amount of grey precipitate (presumably elemental $\mathrm{Pt}$ ) and brought to dryness by rotary evaporation at $40^{\circ} \mathrm{C}$. The crude product is passed over a Sephadex G10 column (FPLC, 
Pharmacia/LBK) to remove $\mathrm{NaCl}$ and then brought to dryness at $40^{\circ} \mathrm{C}$. Anal. calco (found) for $\mathrm{Na}_{2}\left[\left(\mathrm{NH}_{3}\right)_{2} \mathrm{Pt}(\mathrm{dGMP})_{2}\right] \cdot 11 \mathrm{H}_{2} \mathrm{O}$ (1): C, 20.6 (21.2); $\mathrm{H}, 4.5$ (4.0); N, 14.4 (14.0). The yield was $204 \mathrm{mg}(66 \%)$.

Addition of $\mathrm{HCl}$ to an aqueous solution of $1\left(0.09 \mathrm{mmol}, 100 \mathrm{mg} ; 3 \mathrm{~mL} \mathrm{H} \mathrm{H}_{2} \mathrm{O} ; \mathrm{pH} 1.6\right)$ and slow evaporation in air yields within several days $40 \mathrm{mg}(43 \%)$ of colorless crystals of cis-( $\left(\mathrm{NH}_{3}\right)_{2} \mathrm{Pt}(\mathrm{H} \cdot \mathrm{dGMP})_{2} \cdot 6.5 \mathrm{H}_{2} \mathrm{O}$ (2). Anal. calcd (found): $\mathrm{C}, 23.1$ (23.1); $\mathrm{H}, 4.4$ (4.4); $\mathrm{N}$, 16.2 (16.5). Thermogravimetry is consistent with $6.5 \mathrm{H}_{2} \mathrm{O}$ molecules present.

Coordination of the two dGMPs via $\mathrm{N} 7$ to cis- $\left(\mathrm{NH}_{3}\right)_{2} \mathrm{Pt}^{2+}$ is confirmed by the acidbase properties of 1 described in this study; these are in accord with a $\mathrm{Pt}^{2+}-\mathrm{N} 7$ coordination in cis- $\left(\mathrm{NH}_{3}\right)_{2} \mathrm{Pt}(\mathrm{H} \cdot \mathrm{dGMP})_{2}$ only.

\subsection{Materials and Apparatus for the Titration Experiments}

The disodium salt of 2'-deoxyguanosine 5'-monophosphate was purchased from Sigma Chemical Co., St. Louis, MO, USA. Potassium hydrogen phthalate, $\mathrm{NaNO}_{3}, \mathrm{HNO}_{3}$ and $\mathrm{NaOH}$ (Titrisol) (all pro analysi) were obtained from Merck AG, Darmstadt, Germany. The disodium salt of Pt(dGMP) ${ }_{2}^{2-}$ was prepared as described in Section 2.1. For all solutions distilled $\mathrm{CO}_{2}$-free water was used.

The titer of the $\mathrm{NaOH}$ used for the titrations was determined with potassium hydrogen phthalate. The stock solutions of dGMP2- and cis- $\left(\mathrm{NH}_{3}\right)_{2} \mathrm{Pt}(\mathrm{dGMP})_{2}^{2-}$ were freshly prepared daily, and the $\mathrm{pH}$ was adjusted to about 8.4 and 7.6, respectively; the exact concentrations of these solutions (titrated in the presence of an excess of $\mathrm{HNO}_{3}$; see Section 2.3) were measured by titrations with $\mathrm{NaOH}$.

The potentiometric $\mathrm{pH}$ titrations were carried out with a Metrohm E536 potentiograph equipped with an E665 dosimat and a 6.0202.100(NB) combined macro glass electrode.

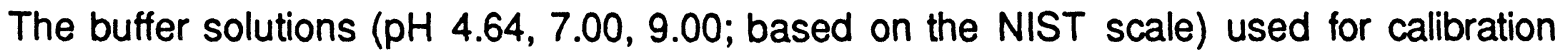
were also from Metrohm AG, Herisau, Switzerland. The direct $\mathrm{pH}$ meter readings were used in the calculations of the acidity constants; i.e., these constants are so-called practical, mixed or Brønsted constants. ${ }^{[10]}$ Their negative logarithms given for aqueous solutions at $I$ $=0.1 \mathrm{M}$ and $25^{\circ} \mathrm{C}$ may be converted into the corresponding concentration constants by subtracting 0.02 from the listed $p K_{a}$ values. ${ }^{[9,10]}$

\subsection{Potentiometric pH Titrations}

The acidity constants $K_{\mathrm{H}_{2}(\mathrm{dGMP})}^{\mathrm{H}}, K_{\mathrm{H}(\mathrm{dGMP})}^{\mathrm{H}}$ and $K_{\mathrm{dGMP}}^{\mathrm{H}}$ of $\mathrm{H}_{2}(\mathrm{dGMP})^{ \pm}$were determined by titrating $50 \mathrm{~mL}$ of aqueous $1.08 \mathrm{mM} \mathrm{HNO}_{3}\left(25^{\circ} \mathrm{C} ; I=0.1 \mathrm{M}, \mathrm{NaNO}_{3}\right)$ in the presence and absence of $0.3 \mathrm{mM}$ or $0.4 \mathrm{mM}$ of dGMP under $\mathrm{N}_{2}$ with $3 \mathrm{~mL} 0.03 \mathrm{M}$ or $2 \mathrm{~mL}$ 
$0.045 \mathrm{M} \mathrm{NaOH}$, respectively, and by using the differences in $\mathrm{NaOH}$ consumption between two such titrations for the calculations. The constants were calculated with an IBM compatible computer with an 80486 processor (connected with a Brother M1509 printer and a Hewlett-Packard 7475A plotter) by a curve-fit procedure using a Newton-Gauss non-linear least-squares program within the $\mathrm{pH}$ range 3.1 to 10.3 , corresponding to about $72 \%$ neutralisation for the equilibrium $\mathrm{H}_{2}(\mathrm{dGMP})^{ \pm} / \mathrm{H}(\mathrm{dGMP})^{-}$and about $85 \%$ neutralisation for the equilibrium dGMP ${ }^{2-} /(\mathrm{dGMP}-\mathrm{H})^{3-}$. The results listed in Table 1 are the averages of 18 independent pairs of titrations.

The acidity constants $K_{\mathrm{Pt}(\mathrm{H} \cdot \mathrm{dGMP})_{2}}^{\mathrm{H}}, K_{\mathrm{Pt}(\mathrm{dGMP})(\mathrm{H} \cdot \mathrm{dGMP})}^{\mathrm{H}}, K_{\mathrm{Pt}(\mathrm{dGMP})_{2}}^{\mathrm{H}}$ and $K_{\mathrm{Pt}(\mathrm{dGMP}-\mathrm{H})(\mathrm{dGMP})}^{\mathrm{H}}$ of cis-( $\left(\mathrm{NH}_{3}\right)_{2} \mathrm{Pt}(\mathrm{H} \cdot \mathrm{dGMP})_{2}$, abbreviated as $\mathrm{Pt}(\mathrm{H} \cdot \mathrm{dGMP})_{2}$, were determined by titrating $25 \mathrm{~mL}$ of aqueous $1.08 \mathrm{mM} \mathrm{HNO}_{3}\left(25^{\circ} \mathrm{C} ; I=0.08-0.1 \mathrm{M}, \mathrm{NaNO}_{3}\right)$ in the presence and absence of $0.4 \mathrm{mM} \mathrm{Pt}(\mathrm{dGMP})_{2}$ under $\mathrm{N}_{2}$ with $2 \mathrm{~mL}$ of $0.03 \mathrm{M} \mathrm{NaOH}$ and by using the differences in $\mathrm{NaOH}$ consumption between two such titrations for the calculations. These calculations were carried out as indicated above within the $\mathrm{pH}$ range 3.6 to 10.3, corresponding to about $1 \%$ neutralisation for the equilibrium $\mathrm{Pt}(\mathrm{H} \cdot \mathrm{dGMP})_{2} / \mathrm{Pt}(\mathrm{dGMP})(\mathrm{H} \cdot \mathrm{dGMP})^{-}$and about $87 \%$ neutralisation for the equilibrium $\mathrm{Pt}(\mathrm{dGMP}-\mathrm{H})(\mathrm{dGMP})^{3-} / \mathrm{Pt}(\mathrm{dGMP}-\mathrm{H})_{2}^{4-}$. The final results given in Table 1 are the averages of 4 independent pairs of titrations.

\section{RESULTS AND DISCUSSION}

\subsection{Definition of the Acidity Constants and Results}

A species with a nucleobase residue is always defined as $L$; hence, such a species may be mono-protonated, e.g. at the phosphate group as in dGMP ${ }^{2-}$ or at the N7 site as in 9-EtG, giving $H(L)$, or it may be deprotonated, e.g. at $H(N 1)$ as in dGMP2-, giving $(L-H)$. Therefore, the acidity constants are defined, e.g., according to equilibria (1) to (3); for the sake of clarity the charges are omitted at the ligand species:

$$
\begin{array}{lll}
\mathrm{H}_{2}(\mathrm{~L}) \rightleftharpoons & \mathrm{H}(\mathrm{L})+\mathrm{H}^{+} \\
& K_{\mathrm{H}_{2}(\mathrm{~L})}^{\mathrm{H}}=[\mathrm{H}(\mathrm{L})]\left[\mathrm{H}^{+}\right] /\left[\mathrm{H}_{2}(\mathrm{~L})\right] \\
\mathrm{H}(\mathrm{L}) & \rightleftharpoons & \mathrm{L}+\mathrm{H}^{+} \\
& K_{\mathrm{H}(\mathrm{L})}^{H} & =[\mathrm{L}]\left[\mathrm{H}^{+}\right] /[\mathrm{H}(\mathrm{L})] \\
\mathrm{L} & \rightleftharpoons & (\mathrm{L}-\mathrm{H})+\mathrm{H}^{+} \\
& K_{\mathrm{L}}^{H} & =[(\mathrm{L}-\mathrm{H})]\left[\mathrm{H}^{+}\right] /[\mathrm{L}]
\end{array}
$$

Hence, e.g., $\mathrm{H}_{2}(\mathrm{dGMP})^{ \pm}\left(=\mathrm{H}_{2}(L)\right)$ is deprotonated at $\mathrm{H}^{+}(\mathrm{N} 7)$ (see Figure 1) according to 
equilibrium (1) giving $H(d G M P)^{-}(=H(L))$ which loses next (eq (2)) the proton from the phosphate group giving dGMP $^{2-}(=\mathrm{L})$; this species may further be deprotonated at its $H(N 1)$ site to give $(d G M P-H)^{3-}(=(L-H)$; eq (3)). Or, to give a further example: coordination of two $\mathrm{H}(\mathrm{dGMP})^{-}$species via $\mathrm{N} 7$ to cis- $\left(\mathrm{NH}_{3}\right)_{2} \mathrm{Pt}^{2+}$ results in cis$\left(\mathrm{NH}_{3}\right)_{2} \mathrm{Pt}(\mathrm{H} \cdot \mathrm{dGMP})_{2}$, a complex which first loses in successive steps two protons from its phosphate residues (cf. also Figure 2, vide infra) according to equilibria (1) and (2); next, one of the two $H(N 1)$ sites of the guanine residues (see Figure 1) is ionized to give $\mathrm{Pt}(\mathrm{dGMP}-\mathrm{H})(\mathrm{dGMP})^{3-}$ according to equilibrium (3) and then in a final step $\mathrm{Pt}(\mathrm{dGMP}-\mathrm{H})_{2}^{4-}$ is formed.

The corresponding acidity constants obtained via potentiometric $\mathrm{pH}$ titrations for the deprotonation of $\mathrm{H}(9-\mathrm{EtG})^{+}$and $\mathrm{H}_{2}(\mathrm{dGMP})^{ \pm}$as well as for their complexes, cis$\left(\mathrm{NH}_{3}\right)_{2} \mathrm{Pt}(9-\mathrm{EtG})_{2}^{2+}$ and cis- $\left(\mathrm{NH}_{3}\right)_{2} \mathrm{Pt}(\mathrm{H} \cdot \mathrm{dGMP})_{2}$, are listed in Table 1 , where the various deprotonation sites are also defined. The constants due to $\mathrm{H}(\mathrm{dCMP})^{-}$and cis$\left(\mathrm{NH}_{3}\right)_{2} \mathrm{Pt}(\mathrm{H} \cdot \mathrm{dCMP})_{2}$ are given for comparison.

From the results summarized in Table 1 it is immediately evident that deprotonation of the $-\mathrm{P}(\mathrm{O})_{2}(\mathrm{OH})^{-}$residues occurs in all species relatively close to $\mathrm{pH} 6$, whereas the proton from the $\mathrm{H}(\mathrm{N} 1)$ site of the guanine moieties is released in the $\mathrm{pH}$ range of about 9. Of some surprise may appear the fact that the $\mathrm{H}^{+}(\mathrm{N} 7)$ site of the positively charged $\mathrm{H}(9-\mathrm{EtG})^{+}$re-

Table 1. Negative Logrithms of Acidity Constants ${ }^{\mathrm{a}}$ of Free and Pt-Coordinated Guanine Derivatives as Determined by Potentiometric $\mathrm{pH}$ Titrations in Aqueous Solution at $25^{\circ} \mathrm{C}$ and $I=0.1 \mathrm{M}\left(\mathrm{NaNO}_{3}\right)$ Together with Some Related Data Determined Under the Same Conditions for Cytidine Species

\begin{tabular}{|c|c|c|c|c|c|}
\hline $\mathrm{H}_{2}(\mathrm{~L}) / \mathrm{H}(\mathrm{L}) / \mathrm{L}$ & $\begin{array}{l}p K_{\mathrm{H}_{2}(L)}^{\mathrm{H}} / \mathrm{p} K_{\mathrm{H}(\mathrm{L})}^{\mathrm{H}} \\
\mathrm{H}^{+}(\mathrm{N} 7)\end{array}$ & $\begin{array}{l}\mathrm{pK} \\
-\mathrm{P}(\mathrm{O})_{2}(\mathrm{OH})^{-}\end{array}$ & $\begin{array}{l}\mathrm{p} K_{\mathrm{H}(\mathrm{L})}^{\mathrm{H}} \\
-\mathrm{P}(\mathrm{O})_{2}(\mathrm{OH})^{-}\end{array}$ & $\begin{array}{l}\mathrm{p} K_{L}^{H} \\
H(N 1)\end{array}$ & $\begin{array}{l}\mathrm{pK} \\
\mathrm{H}(\mathrm{L}-\mathrm{H} 1)\end{array}$ \\
\hline $\mathrm{H}(9-\mathrm{EtG})^{+}[7]$ & $3.27 \pm 0.04$ & & & $9.57 \pm 0.04$ & \\
\hline $\operatorname{Pt}(9-E t G){ }_{2}^{2+}[7]$ & & & & $8.02+0.01$ & $8.67 \pm 0.01$ \\
\hline $\mathrm{H}_{2}(\mathrm{dGMP})^{ \pm}$ & $2.69 \pm 0.03$ & & $6.29 \pm 0.01$ & $9.56 \pm 0.02$ & \\
\hline $\mathrm{Pt}(\mathrm{H} \cdot \mathrm{dGMP})_{2}$ & & $5.57 \pm 0.03$ & $6.29 \pm 0.02$ & $8.73 \pm 0.04$ & $9.48 \pm 0.04$ \\
\hline \multicolumn{2}{|l|}{$H(d C M P)^{-}[9]^{b}$} & & $6.24 \pm 0.01$ & & \\
\hline \multicolumn{2}{|l|}{$\mathrm{Pt}(\mathrm{H} \cdot \mathrm{dCMP})_{2}[9]$} & $5.73 \pm 0.02$ & $6.47 \pm 0.02$ & & \\
\hline \multicolumn{6}{|c|}{$\begin{array}{l}\text { The error limits given are three times the standard error of the mean value or the sum of the } \\
\text { probable systematic errors, whichever is larger. }\end{array}$} \\
\hline b For the deproto & onation of the $\mathrm{H}^{+}($ & 3) site holds: $p K$ & $\mathrm{I}_{2}(\mathrm{dCMP})=4.46$ & $=0.01 .^{[9]}$ & \\
\hline
\end{tabular}


leases its proton with $p K_{\mathrm{a}}=3.27$ only, whereas from the overall neutral (i.e. zwitter ionic) $\mathrm{H}_{2}$ (dGMP) \pm species the release occurs already with $\mathrm{p} K_{\mathrm{a}}=2.69$ (Table 1). This lower basicity of $\mathrm{N} 7$ in $\mathrm{H}$ (dGMP) ${ }^{-}$compared with that of 9-EtG is clearly attributable to the sugar residue, and is thus probably a solvation effect because $\mathrm{H}$ (guanosine) ${ }^{+}$and $\mathrm{H}\left(2^{\prime}\right.$-deoxyguanosine $)^{+}$are $\mathrm{H}^{+}(\mathrm{N} 7)$-deprotonated with $\mathrm{p} K_{\mathrm{a}}=2.11 \pm 0.04^{[11]}$ and $\mathrm{p} K_{\mathrm{a}}=2.30 \pm 0.04,^{[12]}$ respectively. Comparison of the values for $\mathrm{H}(\mathrm{dGuo})^{+}\left(\mathrm{p} K_{\mathrm{a}}=2.30\right)$ and $\mathrm{H}(\mathrm{d} \cdot \mathrm{GMP})^{-}\left(\mathrm{p} K_{\mathrm{a}}=\right.$ 2.69) shows that the expected charge effect is now operating.

\subsection{Some Statistical Considerations on the cis- $\left(\mathrm{NH}_{3}\right)_{2} \mathrm{Pt}(\mathrm{L})_{2}$ Species}

From Figure 2, where a simplified structure of cis- $\left(\mathrm{NH}_{3}\right)_{2} \mathrm{Pt}(\mathrm{H} \cdot \mathrm{dCMP})_{2}$ is shown, it is immediately obvious that this complex as well as cis- $\left(\mathrm{NH}_{3}\right)_{2} \mathrm{Pt}(9-\mathrm{EtG})_{2}^{2+}$ or cis$\left(\mathrm{NH}_{3}\right)_{2} \mathrm{Pt}(\mathrm{H} \cdot \mathrm{dGMP})_{2}$ are 'symmetrical' di- (and tetra-) protonic acids, just like dihydrogen sulfide, $\mathrm{H}_{2} \mathrm{~S}$, or oxalic acid, $\mathrm{HO}(\mathrm{O}) \mathrm{C}-\mathrm{C}(\mathrm{O}) \mathrm{OH}$. The statistical expectation for the separation of the acidity constants of two identical acidic sites in the same molecule, which do not affect each other, is $\Delta p K_{\mathrm{a} / \mathrm{st}}=0.6 .{ }^{[9]}$ This follows from the symmetry properties of, e.g., cis- $\left(\mathrm{NH}_{3}\right)_{2} \mathrm{Pt}(\mathrm{dCMP})_{2}$ : Beginning with $\mathrm{Pt}(\mathrm{H} \cdot \mathrm{dCMP})_{2}$ there are two equivalent ways (see Figure 2) to form $\mathrm{Pt}(\mathrm{dCMP})(\mathrm{H} \cdot \mathrm{dCMP})^{-}$; on the other hand, there are also two equivalent ways for the protonation of $\mathrm{Pt}(\mathrm{dCMP})_{2}^{2-}$ to give $\mathrm{Pt}(\mathrm{dCMP})(\mathrm{H} \cdot \mathrm{dCMP})^{-}$. This means, the

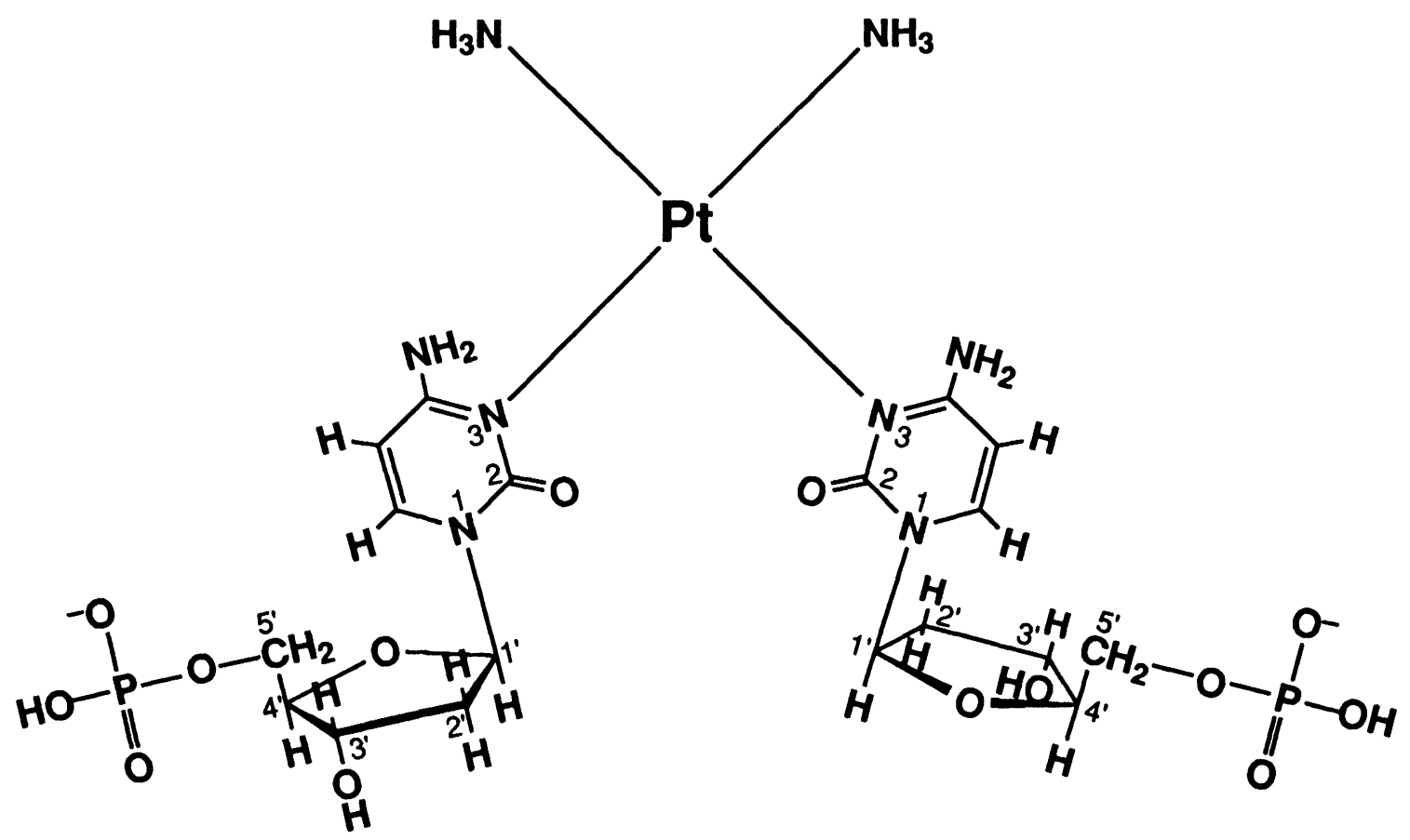

Figure 2. A possible and simplified structure of the $c i s-\left(\mathrm{NH}_{3}\right)_{2} \mathrm{Pt}(\mathrm{H} \cdot \mathrm{dCMP})_{2}$ complex showing the two monoprotonated $-\mathrm{P}(\mathrm{O})_{2}(\mathrm{OH})^{-}$groups. 
formation of the monoprotonated species $\mathrm{Pt}(\mathrm{dCMP})(\mathrm{H} \cdot \mathrm{dCMP})^{-}$is two times favored by a factor of 2 which gives overall a factor of 4 , i.e. $\Delta \mathrm{p} K_{\mathrm{a} / \mathrm{st}}=0.6$.

The above value has to be compared with the following ones:

$$
\begin{aligned}
& \Delta \mathrm{p} K_{\mathrm{a} / \mathrm{Pt}, \mathrm{dCMP}}=\mathrm{p} K_{\mathrm{Pt}(\mathrm{dCMP})(\mathrm{H} \cdot \mathrm{dCMP})}^{\mathrm{H}}-\mathrm{p} K_{\mathrm{Pt}(\mathrm{H} \cdot \mathrm{dCMP})_{2}}^{\mathrm{H}} \\
& =(6.47 \pm 0.02)-(5.73 \pm 0.02) \\
& =0.74 \pm 0.03 \\
& \Delta p K_{\mathrm{a} / \mathrm{Pt}, 9-\mathrm{EtG}}=\mathrm{p} K_{\mathrm{Pt}(9-\mathrm{EtG}-\mathrm{H})(9-\mathrm{EtG})}^{\mathrm{H}}-\mathrm{p} K_{\mathrm{Pt}(9-\mathrm{EtG})_{2}}^{\mathrm{H}} \\
& =(8.67 \pm 0.01)-(8.02 \pm 0.01) \\
& =0.65 \pm 0.01 \\
& \Delta \mathrm{p} K_{\mathrm{a} / \mathrm{Pt}, \mathrm{H} \cdot \mathrm{dGMP}}=\mathrm{p} K_{\mathrm{Pt}(\mathrm{dGMP})(\mathrm{H} \cdot \mathrm{dGMP})}^{\mathrm{H}}-\mathrm{p} K_{\mathrm{Pt}(\mathrm{H} \cdot \mathrm{dGMP})_{2}}^{\mathrm{H}} \\
& =(6.29 \pm 0.02)-(5.57 \pm 0.03) \\
& =0.72 \pm 0.04 \\
& \Delta \mathrm{p} K_{\mathrm{a} / \mathrm{Pt}, \mathrm{dGMP}}=\mathrm{p} K_{\mathrm{Pt}(\mathrm{dGMP}-\mathrm{H})(\mathrm{dGMP})}^{\mathrm{H}}-\mathrm{p} K_{\mathrm{Pt}(\mathrm{dGMP})_{2}}^{\mathrm{H}} \\
& =(9.48 \pm 0.04)-(8.73 \pm 0.04) \\
& =0.75 \pm 0.06
\end{aligned}
$$

It becomes thus evident that all these $\Delta p K_{\mathrm{a}}$ values are close to the statistical expectation; they are on average only about $0.1 \mathrm{pK}$ units larger than $\Delta \mathrm{pK}$ a/st $=0.6$. In other words, the mutual influence that the two corresponding acidic sites in these complexes exert on each other is quite small, which indicates that the distances between these sites (at least in the protonated forms) must be relatively large.

\subsection{Micro Acidity Constants for the cis- $\left(\mathrm{NH}_{3}\right)_{2} \mathrm{Pt}(\mathrm{L})_{2}$ Specles and Acidifying Effect of the N7-Coordinated $\mathrm{Pt}^{2+}$}

The negative logarithms of the two acidity constants, e.g., $\mathrm{p} K_{\mathrm{Pt}(\mathrm{H} \cdot \mathrm{dCMP})_{2}}^{\mathrm{H}}$ and

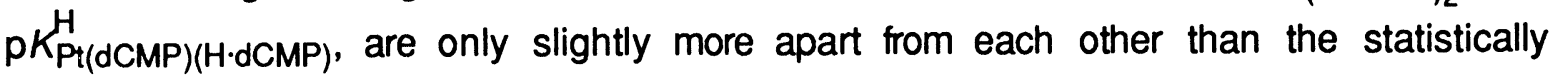
expected $0.6 \mathrm{pK}$ units; this means, the buffer regions of the two species, $\mathrm{Pt}(\mathrm{H} \cdot \mathrm{dCMP})_{2}$ and $\mathrm{Pt}(\mathrm{dCMP})(\mathrm{H} \cdot \mathrm{dCMP})^{-}$, are strongly overlapping. The same also applies to the other $\mathrm{Pt}^{2+}$ complexes considered here; i.e., those formed between cis- $\left(\mathrm{NH}_{3}\right)_{2} \mathrm{Pt}^{2+}$ and 9-EtG, H(dGMP)-, or dGMP ${ }^{2-}$ (see Table 1). Therefore, for a clean quantification of the acidity of the various sites it is necessary to calculate the micro acidity constants for the individual sites. Following known route ${ }^{[13,14]}$ we have summarized in Figure 3 , as an example, the equilibrium scheme for cis-( $\left.\mathrm{NH}_{3}\right)_{2} \mathrm{Pt}(\mathrm{H} \cdot \mathrm{dCMP})_{2}$ defining the micro acidity constants $(k)$ and 
giving their interrelation with the macro acidity constants $(K)$. There are three independent equations (a), (b), and (c), but four unknown constants; ${ }^{[13]}$ however, by taking into account the statistical considerations of Section 3.2 the matter becomes simple in the present case because $p K_{\mathrm{Pt}(\mathrm{H} \cdot \mathrm{dCMP})}^{\mathrm{H}}+\log 2=5.73+0.3=6.03=\mathrm{p} k^{1}=\mathrm{p} k_{1} ;$ the analogues reasoning provides $\mathrm{p} k_{2}$, etc.

The values for the micro acidity constants, $p k^{1}=p k_{1}$ and $p k_{2}=p k^{2}$, for the four cis$\left(\mathrm{NH}_{3}\right)_{2} \mathrm{Pt}(\mathrm{L})_{2}$ complexes appearing in Table 1 are summarized in columns 2 and 3 of Table 2 , respectively. Columns 4 and 5 provide the differences between the $p K_{a}$ values of the free ligands, like 9-EtG or $\mathrm{H}(\mathrm{dGMP})^{-}$, and the values given for $p k^{1}=p k_{1}$ and $p k_{2}=p k^{2}$. Thus, these values quantify the acidifying effect of $\mathrm{Pt}^{2+}$ on the individual sites.

For a general comparison, however, we feel it is more appropriate to take the average of the effect that the two 'symmetrical' sites experience by $\mathrm{Pt}^{2+}$; e.g., the hydrogens in the

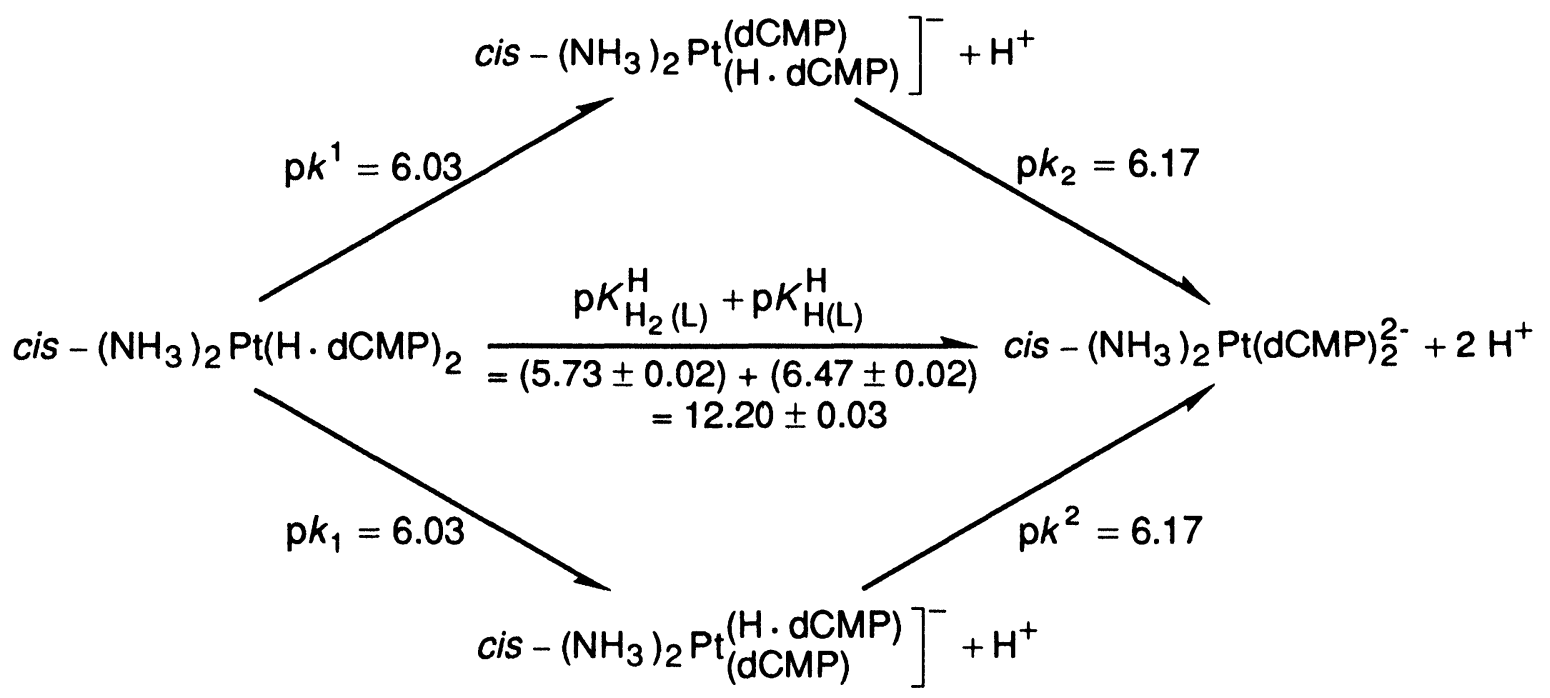

(a) $K_{\mathrm{H}_{2}(\mathrm{~L})}^{\mathrm{H}}=k^{1}+k_{1}$

(b) $\frac{1}{K_{H(L)}^{H}}=\frac{1}{k_{2}}+\frac{1}{k^{2}}$

(c) $K_{\mathrm{H}_{2}(\mathrm{~L})}^{\mathrm{H}} \cdot K_{\mathrm{H}(\mathrm{L})}^{\mathrm{H}}=k^{1} \cdot k_{2}=k_{1} \cdot k^{2}$

Figure 3. Equilibrium scheme for cis- $\left(\mathrm{NH}_{3}\right)_{2} \mathrm{Pt}(\mathrm{H} \cdot \mathrm{dCMP})_{2}$ defining the micro acidity constants $(k)$ and showing their interrelation with the macro acidity constants $(K)$. The arrows indicate the direction for which the acidity constants are defined. Equations (a), (b), and (c) show how the various constants are interlinked with each other. ${ }^{[13]}$ See also text in Section 3.3. 
two $-\mathrm{P}(\mathrm{O})_{2}(\mathrm{OH})^{-}$groups of cis- $\left(\mathrm{NH}_{3}\right)_{2} \mathrm{Pt}(\mathrm{H} \cdot \mathrm{dCMP})_{2}$ (see Figure 2). These average values are listed in column 6 of Table 2. They follow from equation (8),

$$
\Delta p K_{\mathrm{a} / \mathrm{av}}=\frac{1}{2}\left(\Delta \mathrm{p} k_{1}+\Delta \mathrm{p} k_{2}\right)
$$

which is identical with equation (9):

$$
\Delta p K_{\mathrm{a} / \mathrm{av}}=\mathrm{p} K_{\mathrm{H}(\mathrm{L})}^{\mathrm{H}}-\frac{1}{2}\left(\mathrm{p} K_{\mathrm{Pt}(\mathrm{H} \cdot \mathrm{L}) 2}^{\mathrm{H}}+\mathrm{p} K_{\mathrm{Pt}(\mathrm{L})(\mathrm{H} \cdot \mathrm{L})}^{\mathrm{H}}\right)
$$

In equation (9) the difference is taken between the $p K_{\mathrm{a}}$ value of the free ligand and the average of $p K_{\mathrm{a} / 1}$ and $\mathrm{p} K_{\mathrm{a} / 2}$ for the complex formed with two such ligands by their coordination to cis- $\left(\mathrm{NH}_{3}\right)_{2} \mathrm{Pt}^{2+}$. This latter method is identical with the one we have applied before. ${ }^{[7-9]}$ In the footnotes to Table 2 some detailed examples for the calculation procedures indicated above are given.

From the $\Delta \mathrm{p} K_{\mathrm{a} / \mathrm{av}}$ value in row 1 and column 6 of Table 2 it is evident that the acidifying effect on the two $\mathrm{H}(\mathrm{N} 1)$ sites of $\mathrm{Pt}^{2+}$ coordinated to the N7 sites in the guanine residues of cis- $\left(\mathrm{NH}_{3}\right)_{2} \mathrm{Pt}(9-\mathrm{EtG})_{2}^{2+}$ is quite significant $\left(\Delta \mathrm{p} K_{\mathrm{a} / \mathrm{av}}=1.23\right)$. The corresponding

Table 2. Micro Acidity Constants for cis- $\left(\mathrm{NH}_{3}\right)_{2} \mathrm{Pt}(\mathrm{L})_{2}$ Species (defined in analogy to Figure 3) and Extent of the Acidification ( $\Delta \mathrm{p} K_{\mathrm{a} / \mathrm{av}}$; (eqs (8) and (9)) ${ }^{\mathrm{a}}$ by NucleobaseCoordinated cis- $\left(\mathrm{NH}_{3}\right)_{2} \mathrm{Pt}^{2+}$ on $\mathrm{H}(\mathrm{N} 1)$ Sites and $-\mathrm{P}(\mathrm{O})_{2}(\mathrm{OH})^{-}$Groups $\left(25^{\circ} \mathrm{C} ; I=0.1 \mathrm{M}\right.$, $\mathrm{NaNO}_{3}$ )

\begin{tabular}{lcclcc}
\hline $\mathrm{H}_{2}(\mathrm{~L})$ & $p k^{1}=p k_{1}{ }^{\mathrm{b}}$ & $\mathrm{p} k_{2}=p k^{2 \mathrm{~b}}$ & $\Delta p k_{1}{ }^{\mathrm{c}, \mathrm{d}}$ & $\Delta p k_{2}{ }^{\mathrm{d}}$ & $\Delta p K_{\mathrm{a} / \mathrm{av}}{ }^{\mathrm{a}, \mathrm{e}}$ \\
\hline $\mathrm{Pt}(9-\mathrm{EtG})_{2}^{2+}$ & 8.32 & 8.37 & $1.25^{\mathrm{c}}$ & 1.20 & 1.23 \\
$\mathrm{Pt}(\mathrm{H} \cdot \mathrm{dGMP})_{2}$ & 5.87 & 5.99 & $0.42^{\mathrm{d}}$ & $0.30^{\mathrm{d}}$ & $0.36^{\mathrm{e}}$ \\
$\mathrm{Pt}(\mathrm{dGMP})_{2}^{2-}$ & 9.03 & 9.18 & 0.53 & 0.38 & 0.46 \\
$\mathrm{Pt}(\mathrm{H} \cdot \mathrm{dCMP})_{2}$ & $6.03^{\mathrm{b}}$ & 6.17 & 0.21 & 0.07 & 0.14 \\
\hline
\end{tabular}

a The sites of acidification are for rows 1 and $3 \mathrm{H}(\mathrm{N} 1)$ and for rows 2 and $4-\mathrm{P}(\mathrm{O})_{2}(\mathrm{OH})^{-}$.

b See text in Section 3.3 and Figure 3.

c Example for row 1 and column 4:

$$
\Delta p k_{1}=p K_{9-E t G}^{H}-p k_{1}=(9.57 \pm 0.04)-(8.32 \pm 0.01)=1.25 \pm 0.04
$$

d Examples for row 2 and columns 4 and 5 :

$$
\begin{aligned}
& \Delta p k_{1}=p K_{H}^{H}(d G M P)-p k_{1}=(6.29 \pm 0.01)-(5.87 \pm 0.03)=0.42 \pm 0.03 \\
& \Delta p k_{2}=p K_{H(d G M P)}^{H}-p k_{2}=(6.29 \pm 0.01)-(5.99 \pm 0.02)=0.30 \pm 0.02
\end{aligned}
$$

- Example for row 2 and column 6:

$$
\begin{aligned}
\Delta p K_{\mathrm{a} / \mathrm{av}} & =1 / 2\left(\Delta \mathrm{p} k_{1}+\Delta \mathrm{p} K_{2}\right)=1 / 2[(0.42 \pm 0.03)+(0.30 \pm 0.02)]=0.36 \pm 0.04 \\
& =p K_{\mathrm{H}(\mathrm{dGMP})}^{\mathrm{H}}-1 / 2\left(\mathrm{p} K_{\mathrm{Pt}(\mathrm{H} \cdot d G M P)_{2}}^{H}+\mathrm{p} K_{\mathrm{Pt}(\mathrm{dGMP})(H \cdot d G M P)}^{H}\right) \\
& =(6.29 \pm 0.01)-1 / 2[(5.57 \pm 0.03)+(6.29 \pm 0.02)]=0.36 \pm 0.04
\end{aligned}
$$


effect in cis- $\left(\mathrm{NH}_{3}\right)_{2} \mathrm{Pt}(\mathrm{dGMP})_{2}^{2-}$ is considerably lower $\left(\Delta \mathrm{p} K_{\mathrm{a} / \mathrm{av}}=0.46\right)$ which is probably the result of the counterbalance in the charge by the two $-\mathrm{P}(\mathrm{O})_{3}^{2-}$ residues. On the other hand the effect of the N7-coordinated $\mathrm{Pt}^{2+}$ on the two $-\mathrm{P}(\mathrm{O})_{2}(\mathrm{OH})^{-}$residues in cis$\left(\mathrm{NH}_{3}\right)_{2} \mathrm{Pt}(\mathrm{H} \cdot \mathrm{dGMP})$ is of the same order $\left(\Delta \mathrm{p} K_{\mathrm{a} / \mathrm{av}}=0.36\right)$, which is kind of surprising because in this latter case only a through-space effect can operate; this is different in the case of $\mathrm{H}(\mathrm{N} 1)$ and the N7-coordinated $\mathrm{Pt}^{2+}(\Delta \mathrm{pK}$ a/av $=0.46)$ because here both sites are part of the aromatic purine residue. Why the acidifying effect of $\mathrm{Pt}^{2+}$ in cis- $\left(\mathrm{NH}_{3}\right)_{2} \mathrm{Pt}(\mathrm{H} \cdot \mathrm{dCMP})_{2}$ $\left(\Delta p K_{a / a v}=0.14 \pm 0.03\right)$, where it is N3-bound, is by about $0.2 p K$ units lower than in cis$\left(\mathrm{NH}_{3}\right)_{2} \mathrm{Pt}(\mathrm{H} \cdot \mathrm{dGMP})_{2}\left(\Delta \mathrm{pK} K_{\mathrm{a} / \mathrm{av}}=0.36 \pm 0.04\right)$ despite the fact that in both instances the two $-\mathrm{P}(\mathrm{O})_{2}(\mathrm{OH})^{-}$groups are acidified, is not clear. Maybe the spatial orientation of the $\mathrm{Pt}^{2+}$-coordinated nucleotides is different.

\section{CONCLUSIONS}

It is evident from the present study that a nucleobase-coordinated cis- $\left(\mathrm{NH}_{3}\right)_{2} \mathrm{Pt}^{2+}$ affects only little the basicity of phosphate residues of nucleoside 5'-monophosphates; the same may be surmised for the phosphate groups in the backbone of DNA. As the basicity of phosphate groups is only slightly lowered, one may assume that the metal ion affinity of these groups is still quite pronounced; in fact, for cis- $\left(\mathrm{NH}_{3}\right)_{2} \mathrm{Pt}(\mathrm{dCMP})_{2}^{2-}$ this has already been proven. ${ }^{[9]}$ Consequently, one may suggest that, e.g., $\mathrm{Mg}^{2+}$ binding to the phosphate backbone of platinated DNA is not much inhibited by the nucleobase-bound $\mathrm{Pt}^{2+}$.

A further interesting observation is the rather significant acidification of the $H(N 1)$ sites of guanine residues by $\mathrm{N} 7$-coordinated $\mathrm{Pt}^{2+}$. This suggests, and evidence pointing into this direction has already been found, $[7]$ that in this way the $H(N 1)$ site is transformed into an even better $\mathrm{H}$ donor suitable for hydrogen bonding than it is the case in the uncomplexed guanine residue.

\section{ACKNOWLEDGEMENTS}

The competent technical assistance of Mrs. Rita Baumbusch in the preparation of the manuscript is gratefully acknowledged. This study was supported by the Swiss National Science Foundation (H.S.), the 'Deutsche Forschungsgemeinschaft' (B.L.), the 'Fonds der Chemischen Industrie' (B.L.), and the Human Capital and Mobility programme (for B.L. via the Commission of the European Communities in Brussels and for H.S. via the Swiss Federal Office for Education and Science in Berne). This research is also part of the COST D1 programme and received in this context support (H.S.) from the Swiss Federal Office for 
Education and Science. B.S. is grateful for a leave of absence from the Zhongshan (Sun Yatsen) University in Guangzhou, People's Republic of China.

\section{REFERENCES}

1. Bloemink, M. J.; Reedijk, J.: Met. lons Biol. Syst. (1996) 32, 641-685.

2. Whitehead, J. P.; Lippard, S. J.: Met. Ions Biol. Syst. (1996) 32, 687-726.

3. Lippert, B.: Prog. Inorg. Chem. (1989) 37, 1-97.

4. Lippert, B.: Biometals (1992) 5, 195-208.

5. Sigel, H.: Chem. Soc. Reviews (1993) 22, 255-267.

6. Sigel, H.; Song, B.: Met. lons Biol. Syst. (1996) 32, 135-205.

7. Schröder, G.; Lippert, B.; Sabat, M.; Lock, C. J. L.; Faggiani, R.; Song, B.; Sigel, H.: J. Chem. Soc. Dalton Trans. (1995), 3767-3775.

8. Song, B.; Feldmann, G.; Bastian, M.; Lippert, B.; Sigel, H.: J. Inorg. Biochem. (1995) $59,141$.

9. Song, B.; Feldmann, G.; Bastian, M.; Lippert, B.; Sigel, H.: Inorg. Chim. Acta (1995) 235, 99-109.

10. Sigel, H.; Zuberbühler, A. D.; Yamauchi, O.: Anal. Chim. Acta (1991) 255, 63-72.

11. Sigel, H.; Massoud, S. S.; Corfù, N. A.: J. Am. Chem. Soc. (1994) 116, 2958-2971.

12. Sigel, H.; Song, B.; Lippert, B.; et al.: results to be published.

13. Martin, R. B.: Met. Ions Biol. Syst. (1979) 9, 1-39.

14. Sigel, H.; Massoud, S. S.; Tribolet, R.: J. Am. Chem. Soc. (1988) 110, 6857-6865.

Received: March 23, 1996 - Accepted: April 25, 1996 -

Received in revised camera-ready format: April 26, 1996 